\title{
Methods for the assessment of isoenzymes activity in sunflower seeds ${ }^{1}$
}

\author{
Gabrielle de Faria ${ }^{2 *}$, Renato Mendes Guimarães ${ }^{2}$, Everson Reis Carvalho ${ }^{3}$, \\ Diego de Sousa Pereira ${ }^{2}$
}

\begin{abstract}
Enzyme activity detection in seeds allows the assessment of the deterioration process in the early stages. In this context, the objective was to assess the effectiveness and the degree of similarity between the results of izoenzymes activity using different methods, as follows: spectrophotometry, visual analysis after electrophoresis, evaluation of the bands nodes gels with software GelAnalyzer. 250 hybrid seeds were submitted to artificial aging to form four lots with differences in physiological quality. In addition to the enzymatic determinations, physiological germination tests, emergence and emergence speed index were performed. It was concluded that there are differences in results according to the methods used; the results were consistent between test methods and correlated with physiological results when the catalase enzyme was evaluated; and in the isozyme analysis of superoxide dismutase and alcohol dehydrogenase there was a divergence among the results of the methodologies, and according to such, the relationship to seeds physiological quality.
\end{abstract}

Index terms: seed quality, deterioration, enzymatic changes.

\section{Métodos para a avaliação da atividade de isoenzimas em sementes de girassol}

RESUMO - A detecção da atividade enzimática em sementes permite avaliar o processo de deterioração ainda nos primeiros estádios. Nesse contexto, objetivou-se avaliar a similaridade entre os resultados da atividade de isoenzimas, utilizando-se diferentes métodos: espectrofotometria, análise visual dos géis de poliacrilamida após eletroforese e avaliação das bandas nós géis com auxílio do software GelAnalyzer, e sua relação com a qualidade fisiológica das sementes. Foram utilizadas sementes do híbrido 250 da empresa Heliagro submetidas ao envelhecimento artificial para a constituição de quatro sublotes com diferenças na qualidade fisiológica. Além das determinações enzimáticas, foram realizados os testes fisiológicos de germinação, emergência e índice de velocidade de emergência. Concluiu-se que há diferenças de resultados conforme o método utilizado; os resultados foram consistentes entre métodos de análise e correlacionados com os resultados fisiológicos quando a enzima avaliada foi a catalase; para a análise isoenzimática da superóxido dismutase e da álcool desidrogenase houve divergência entre os resultados das metodologias, e em função dessas a relação com a qualidade fisiológica das sementes.

Termos para indexação: qualidade de sementes, deterioração, alterações enzimáticas.

\section{Introduction}

Sunflower crops are outstanding for being an option for crop rotation and succession planting, a protein source and the quality of their oil, being considered a functional food. Because of the growing interest in sunflower cultivation, the entire production chain of seeds has shown progress and is faced with challenges to achieve and maintain the seeds quality to meet the market needs and expectations.

In sunflower seeds and seeds from other species, deterioration occurs gradually, showing a sequence of

${ }^{1}$ Submitted on 04/27/2015. Accepted for publication on 06/24/2015. ${ }^{2}$ Departamento de Agricultura, UFLA, Caixa Postal 3037, 37200-000 Lavras, MG, Brasil. biochemical or physiological events, such as damage to the membrane system and its permeability, which shows the first deterioration events and is strongly related to the increase in respiratory rate of tissues, changes in enzymatic activity, reduced reserve tissues, decrease in germination speed and capacity and growth of normal seedlings (Santos et al., 2004).

Thus, enzymatic activity is a leading indicator of degenerative changes in seeds. According to Costa et al. (2008), there is a possibility of using isoenzymatic markers as a tool in determining biochemical changes resulting from the deteriorating process of the seeds, being stressed by

${ }^{3}$ Instituto de Ciências Agrárias, UFU, 38500-000 - Monte Carmelo, MG, Brasil. *Corresponding author <gabifaria@gmail.com> 
several authors (Abreu et al., 2014; Carvalho et al., 2014; Santos et al., 2005). However, the results obtained by visual inspection of the bands in gels after electrophoresis can be very subjective if no programs that assist in the detection and analysis of the isoforms are used. Another technique that allows the characterization of enzymatic activity is the spectrophotometry method quantitatively determining the enzyme activity by absorbance. This technique is, among other advantages, quick, produces less waste and analyzes without risking subjectivity.

Given the above, the objective of this study was to evaluate the similarity between the results of isoenzyme activity, assessed by spectrophotometry, visual analysis and with software Gel Analyzer (Lazar and Lazar, 2010) of the bands in the gels after electrophoresis and their relation to physiological quality in sunflower seeds with different levels of deterioration.

\section{Material and Methods}

Seeds from one lot of hybrid 250 sunflower produced by the company Heliagro Agricultura e Pecuária Ltda. were used. The experiment was performed at Central Laboratory of Seeds, Department of Agriculture, University Federal of Lavras, from September to December 2013.

The sunflower seed sublots were submitted to accelerated aging for different times to simulate lots with different physiological quality levels. Then these sublots were subjected to physiological assessments and three enzymatic systems to verify the similarity of the results between the methods of visual analysis of the bands on polyacrylamide gels, analysis of the bands of the gels by software GelAnalyzer and analysis by spectrophotometry, and their relation to physiological quality. The verification of effectiveness and similarity was based on analyses usually performed for each of the methods, i.e., visual analysis of the bands, presence, absence or intensity of the bands on the gels, image analysis of the bands by the intensity and size, with subsequent transformation in values by software GelAnalyzer and enzymatic activity by spectrophotometry in $\mu \mathrm{M} \mathrm{g}^{-1}$. $\min ^{-1}$.

Constitution of lots with different physiological qualities - the seeds were placed on an aluminum screen tray, set inside plastic (Gerbox type) boxes, which functioned as an individual compartment (mini-camera). Below the tray with seeds and inside the boxes $40 \mathrm{~mL}$ of distilled water were placed. Then, the boxes were kept in an incubator at $42{ }^{\circ} \mathrm{C}$ for periods of zero, 48, 72 and 96 hours and, subsequently, the lots obtained were stored in multiwall paper bags in uncontrolled laboratory conditions (mean $25{ }^{\circ} \mathrm{C}$ and $70 \% \mathrm{RH}$ ) for 30 days. The lots were identified with numbers 1, 2, 3 and 4, for times zero, 48,
72 and 96 hours of artificial aging, respectively.

Water content of the seeds - determination of the water content of the seeds was carried out before and after the artificial aging treatments, by the oven method at a temperature of $105 \pm 3{ }^{\circ} \mathrm{C}$ for 24 hours with two samples per lot of seeds (Brasil, 2009). The results were expressed in percentage. The water content of the seeds (Table 1) exposed to the accelerated aging treatments was not adjusted for performing the tests; however, the seeds were maintained for 30 days under ambient conditions to equalize the water content, having at the end of the period $11.89 \%$ water content.

Germination test - four replicates of 50 seeds were used on a paper roll moistened with distilled water in the amount of 2.5 times the weight of the dry paper, which were kept in a germinator set at a constant temperature of $25^{\circ} \mathrm{C}$ for a period of ten days. The evaluation was conducted on the fourth and tenth days after implementation, according to criteria established by the Regras para Análise de Sementes (RAS; Rules for Seed Testing) (Brasil, 2009).

First germination count - it was determined together with the germination test. Normal seedlings were computed on the germination test count held on the fourth day after implementing the test. The results were expressed in percentage.

Emergence percentage and Emergence Speed Index four replicates of 50 seeds sown in a substrate mixture of soil and sand at a ratio of 2:1 in trays were used and maintained in a growth chamber with a constant temperature of $25^{\circ} \mathrm{C}$. Daily counts were performed from the beginning of seedling emergence, computing the number of emerged seedlings until stabilization of the stand. The results were expressed in percentage. Concurrent to the emergence test, the emergence speed index was determined following the methodology proposed by Maguire (1962).

Quantification by spectrophotometry - the extract was obtained by macerating seeds without the integument in liquid nitrogen, and from this one were taken $0.05 \mathrm{~g}$, to which were added $1.5 \mathrm{~mL}$ of extraction buffer containing: $1.47 \mathrm{~mL}$ of potassium phosphate buffer $0.1 \mathrm{M}(\mathrm{pH} 7.0), 15 \mu \mathrm{L}$ of EDTA (Ethylenediaminetetraacetic acid) $0.1 \mathrm{M}(\mathrm{pH} 7.0)$, ascorbic acid $0.001 \mathrm{M}$ and $12 \mathrm{mg}$ of PVP (polyvinylpyrrolidone) and then centrifuged at $13,000 \mathrm{xg}$ for 30 minutes at $4{ }^{\circ} \mathrm{C}$ for extraction of the enzyme superoxide dismutase (SOD) and catalase (CAT); for the enzyme alcohol dehydrogenase (ADH) the extract was obtained by macerating seeds without the integument in liquid nitrogen and thus separated $0.05 \mathrm{~g}$ to which was added $1 \mathrm{~mL}$ extraction buffer containing Tris $\mathrm{HCl}$ $0.50 \mathrm{M}$ (pH 6.8), glycerol 15\%, 0.1\% pf $\beta$-mercaptoethanol and PMSF (phenylmethanesulfonyl fluoride) $0.1 \mathrm{M}$; and centrifuged at $13000 \mathrm{xg}$ for 15 minutes at $4{ }^{\circ} \mathrm{C}$. For all the 
enzymes, the supernatants were collected and applied to ELISA microplates of 96 wells, in triplicates.

The SOD activity was evaluated by the enzyme's ability to inhibit the photoreduction of nitro blue tetrazolium (NBT), as proposed by Giannopolitis and Ries (1977), with modifications. $10 \mu \mathrm{L}$ of the enzymatic extract were added at $190 \mu \mathrm{L}$ of the incubation medium. The UV acrylic plate containing incubation medium and the sample was illuminated with a $20 \mathrm{~W}$ fluorescent lamp for seven minutes. Readings were taken at $560 \mathrm{~nm}$ by spectrophotometry. One unit of SOD corresponds to the amount of enzyme capable of inhibiting by $50 \%$ the photoreduction of NBT under the assay conditions. The CAT activity was assessed according to Havir and McHale (1987), wherein an aliquot of $10 \mu \mathrm{L}$ of the enzymatic extract was added to $190 \mu \mathrm{L}$ of the incubation medium. This enzyme activity was determined by the decrease in absorbance at $240 \mathrm{~nm}$ every 15 seconds for three minutes, monitoring the consumption of hydrogen peroxide by spectrophotometry.

The ADH activity was assessed by adding an aliquot of $9 \mu \mathrm{L}$ of the enzymatic extract at $190 \mu \mathrm{L}$ of the incubation medium; adding $1 \%$ ethanol ( $/ \mathrm{v})$ at the time of reading, carried out by spectrophotometry at $340 \mathrm{~nm}$ for three minutes, following the reduction of NAD+ (Nicotinamide adenine dinucleotide), according to Yamanoshita et al. (2005), with modifications. The enzymatic activity calculation was given by the amount of NADH produced by minute of incubation.

Enzymatic analysis by electrophoresis - seeds without the integument were ground in the presence of PVP and liquid nitrogen and subsequently stored at $-86^{\circ} \mathrm{C}$. For the extraction, $300 \mu \mathrm{L}$ were added of the extraction buffer Tris $\mathrm{HCl} 0.2 \mathrm{M}$ ( $\mathrm{pH} 8.0$ ) and $0.1 \%$ of $\beta$-mercaptoethanol. The material was placed in a refrigerator for 12 hours and then centrifuged at $18,000 \mathrm{~g}$ for 30 minutes at $4{ }^{\circ} \mathrm{C}$ (Alfenas, 2006). The electrophoretic run occurred in a system of polyacrylamide gels $7.5 \%$ (separator gel) and $4.5 \%$ (concentrator gel). The gel/electrode system used was Tris-glycine $\mathrm{pH}$ 8.9. $50 \mu \mathrm{L}$ of the supernatant of the samples were applied to the gel and the electrophoretic run conducted at $120 \mathrm{~V}$ for five hours. The gels were developed for the enzymes SOD, CAT and ADH, according to Alfenas (2006).

Statistical procedure - a completely randomized design was used, with four replications of 50 seeds for the physiological tests, and three repetitions for the enzymatic analyses. For the visual analysis of the gels there were no statistical analyses, the evaluation was by presence, absence and intensity of the bands. The data analysis of variance was performed using the statistical program Sisvar (Ferreira, 2011), at $5 \%$ probability by F-test. The comparison of means was performed using the Scott-Knott test, at 5\%.

\section{Results and Discussion}

The water content of the seeds of the lots increased with the exposure time of the seeds to artificial aging (Table 1), thus being effective for changing the seeds metabolic activity.

According to Braz et al. (2008), accelerated aging for 48, 72 and 96 hours is sufficient for classifying lots of sunflower seeds at different levels of vigor. However, the quality levels of the seed lots aged for times of 0,48 and 72 hours, in the present study, were similar when evaluated by the germination test; only 96 hours showed lower germination (Table 1). These results differ from those found by Maeda et al. (1985) who, studying the sunflower seeds response to the accelerated aging test, found that the germination power of all lots studied decreased as they increased the period of stay in the aging chamber.

Table 1. Average moisture of seed water content (WC), germination $(G)$, emergence $(E)$, emergence speed index (ESI) of artificially aged sunflower seeds.

\begin{tabular}{cccccc}
\hline $\begin{array}{c}\text { Aging } \\
\text { (hours) }\end{array}$ & $\begin{array}{c}\text { WC } \\
(\%)\end{array}$ & Lots & $\begin{array}{c}\text { G } \\
(\%)\end{array}$ & $\begin{array}{c}\text { E } \\
(\%)\end{array}$ & ESI \\
\hline 0 & 7.72 & 1 & $98.00 \mathrm{a}$ & $89.50 \mathrm{a}$ & $8.33 \mathrm{a}$ \\
48 & 18.45 & 2 & $99.00 \mathrm{a}$ & $86.00 \mathrm{a}$ & $8.00 \mathrm{a}$ \\
72 & 20.82 & 3 & $97.00 \mathrm{a}$ & $79.50 \mathrm{~b}$ & $7.23 \mathrm{~b}$ \\
96 & 21.47 & 4 & $92.50 \mathrm{~b}$ & $70.00 \mathrm{c}$ & $6.28 \mathrm{c}$ \\
\hline CV (\%) & - & & 2.35 & 6.63 & 7.2 \\
\hline
\end{tabular}

Means followed by the same letter were grouped by Scott-Knott test $(\mathrm{p}<0.05)$.

For seedling emergence, the highest percentages were observed in lots 1 and 2, which were similar to each other and superior to lot 3; for lot 4, 96 hours of aging, the lowest emergence was observed (Table 1). A similar result was observed for the emergence speed index (Table 1). It is observed that lots with longer exposure time to stress by artificial aging were those with minor emergences, indicating that these conditions were able to change the seed vigor. Braz and Rossetto (2009) have obtained a positive correlation between vigor and the emergence of sunflower seedlings in the field, in a work in which the seeds were aged by 72 e 96 hours at $42{ }^{\circ} \mathrm{C}$.

Enzymes such as superoxide dismutase (SOD) and catalase (CAT) act as detoxification mechanisms, removing free radicals from the cells (Rosa et al., 2005). SOD transforms superoxide into hydrogen peroxide $\left(\mathrm{H}_{2} \mathrm{O}_{2}\right)$, acting as the first line of defense against reactive oxygen species (Nakada et al., 2011).

By analyzing Figure 1 it is not possible to visually detect changes in the profile of the SOD activity among the four lots studied. When submitting the same Figure 1 to the software GelAnalyzer, it can be seen that the volume does not differ among lots 2, 3 and 4, and the greatest volume was obtained 
for lot 1 (Figure 2), indicating a difference among the test results. Baliza et al. (2012), when working with superoxide dismutase in coffee beans using visual analysis of bands on gels, were also able to observe differences of enzymes due to seeds maturation stages. Carvalho et al. (2014), studying enzymatic changes by analysis of gels in different soybean cultivars, have found changes to the SOD activity in only one studied soybean cultivar.

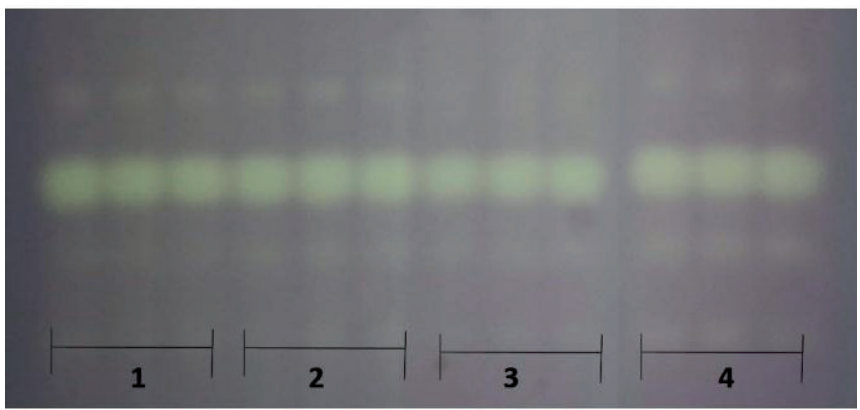

Figure 1. Zymogram of SOD (Superoxide dismutase) enzyme activity for four lots of sunflower seeds artificially aged for zero (1), 48 (2), 72 (3) and 96 (4) hours.

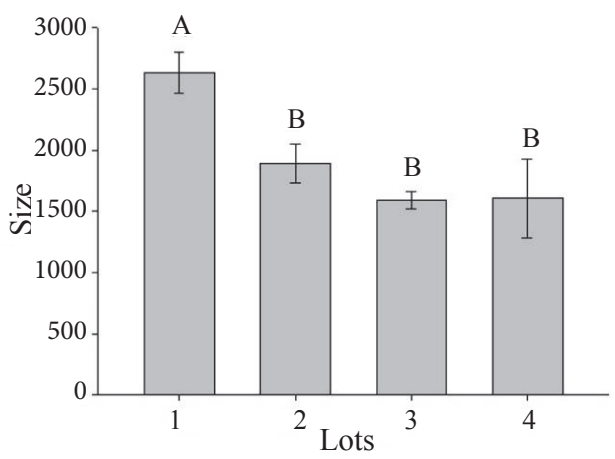

Figure 2. Quantification of the superoxide dismutase (SOD) enzyme activity in lots of sunflower seeds with different levels of vigor by software GelAnalyzer.

Means followed by the same letter were grouped together by the Scott-Knott test $(\mathrm{p}<0.05)$. Vertical bars indicate the standard deviation of the means.

By spectrophotometry, the activity of the SOD enzyme did not differ among lots (Figure 3).

CAT activity converts hydrogen peroxide into water and oxygen (Nakada et al., 2011), functioning as a second line of defense in the cell. The decrease in CAT activity is associated with reduced seed physiological quality, since free radicals cause oxidation of unsaturated fatty acids, causing damage to membranes (Rosa et al., 2005).

During the process of seeds deterioration, decrease in CAT activity occurs by its gradual inactivation or reduction and stoppage of its synthesis (Marcos-Filho, 2005).
Visually analyzing the CAT expression in the polyacrylamide gel after electrophoresis, Figure 4, a reduction in CAT activity is noted with increasing time of aging of the seeds. The correlation between the reduction of catalase activity and the reduction of the seeds germination percentage can be observed in the value obtained by seeds of lot 4,96 hours of aging. But for emergence percentage and ESI this relationship was observed from 72 hours (Table 1).

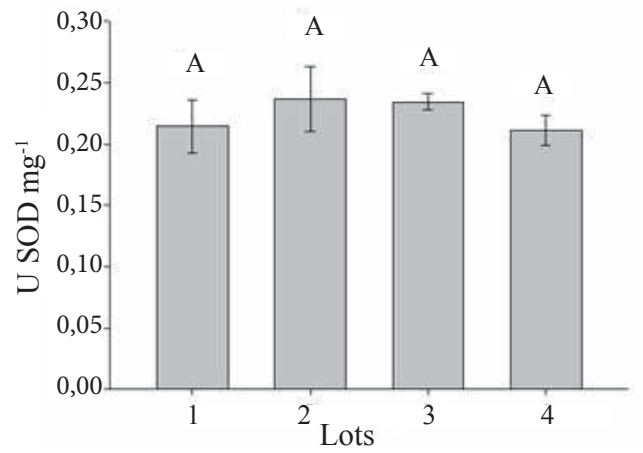

Figure 3. Quantification of superoxide dismutase (SOD) enzyme activity in lots of sunflower seeds with different levels of vigor by spectrophotometry.

Means followed by the same letter were grouped together by the Scott-Knott test $(\mathrm{p}<0.05)$. Vertical bars indicate the standard deviation of the means.

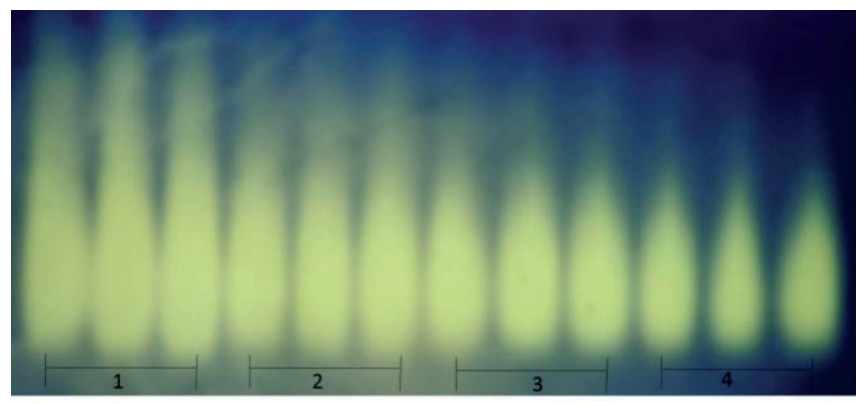

Figure 4. Zymogram of CAT (catalase) enzyme activity for four lots of sunflower seeds artificially aged for zero (1), 48 (2), 72 (3) and 96 (4) hours.

In this sense, by the quantification of the CAT activity by software GelAnalyzer, only lot 1, not aged, differed from the others (Figure 5). But when analyzing the activity by spectrophotometry, the enzymatic activity values obtained for lots 1 and 2 were superior and different from those obtained for lots 3 and 4, which were equal to each other (Figure 6). For Ataíde et al. (2012) and Berjak (2006), reducing the activity of enzymes such as catalase is related to loss of seeds viability and vigor.

The enzyme alcohol dehydrogenase $(\mathrm{ADH})$ operates in the anaerobic respiration mechanism, reducing acetaldehyde 
to ethanol and oxidizing NADH to NAD ${ }^{+}$(Bray et al., 2000). Acetaldehyde accelerates the seeds deterioration (Zhang et al., 1994). Carvalho et al. (2014) have concluded that in the soybean cultivars seeds, which showed better physiological quality, the greatest expressions of enzymes ADH were found. Therefore, with the increase in ADH activity and the resulting reduction of acetaldehyde, the seeds are further protected against the deleterious action of this compound. Based on the zymogram of ADH (Figure 7), it can be noted by visual observation that there was a reduction of ADH enzyme activity only in lot 3 .

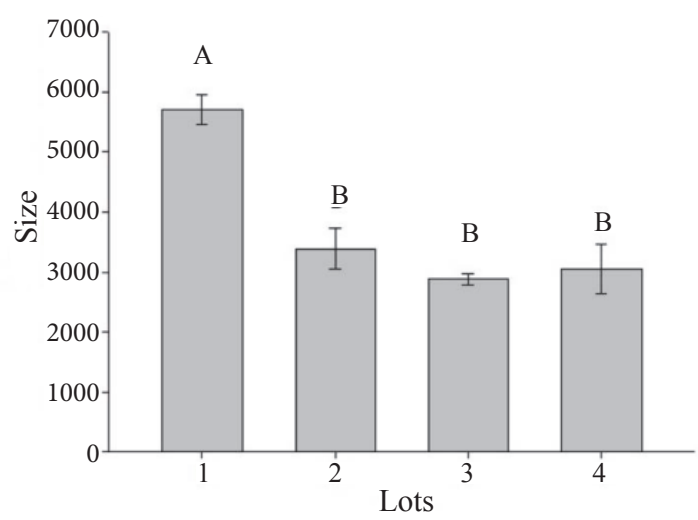

Figure 5. Quantification of catalase enzyme activity in lots of sunflower seeds with different levels of vigor by software GelAnalyzer.

Means followed by the same letter were grouped together by the Scott-Knott test $(p<0.05)$. Vertical bars indicate the standard deviation of the means.

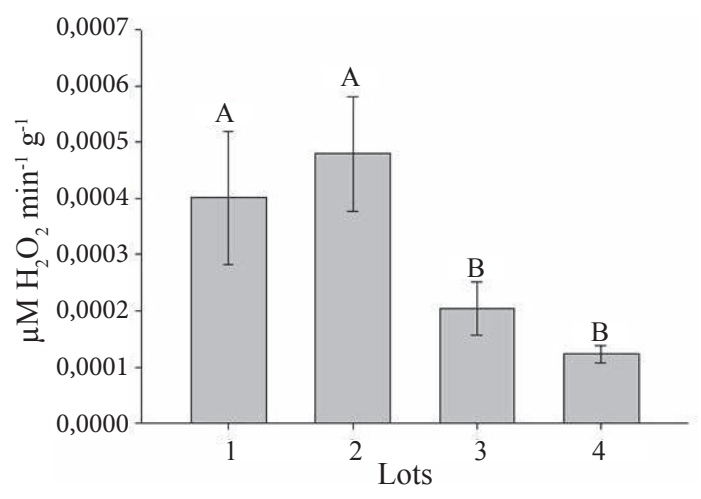

Figure 6. Quantification of the catalase enzyme activity in lots of sunflower seeds with different levels of vigor by spectrophotometry.

Means followed by the same letter were grouped together by the Scott-Knott test $(\mathrm{p}<0.05)$. Vertical bars indicate the standard deviation of the means.

When analyzing Figure 8, data from software GelAnalyzer, it is possible to find a matching to Figure 7, namely, just in lot 3 there was a reduction of ADH activity. However, according to the results observed by means of the spectrophotometer for ADH (Figure 9), the enzymatic activities were the same for lots 1, 2, 3 and lower for lot 4, a contrasting result when compared to that observed with other methods but related to seed physiological quality, since this lot had lower values for all parameters assessed (Table 1).

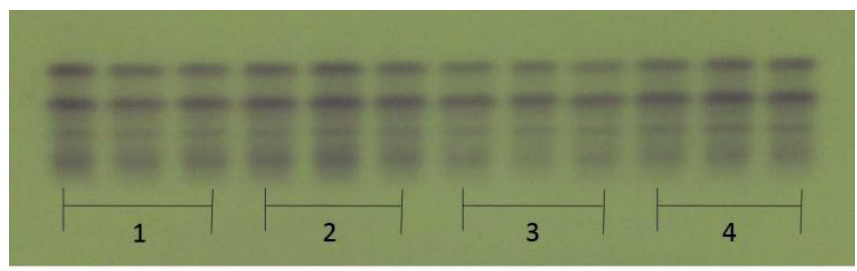

Figure 7. Zymogram of ADH (Alcohol dehydrogenase) enzyme activity for four lots of sunflower seeds artificially aged for zero (1), 48 (2), 72 (3) and 96 (4) hours.

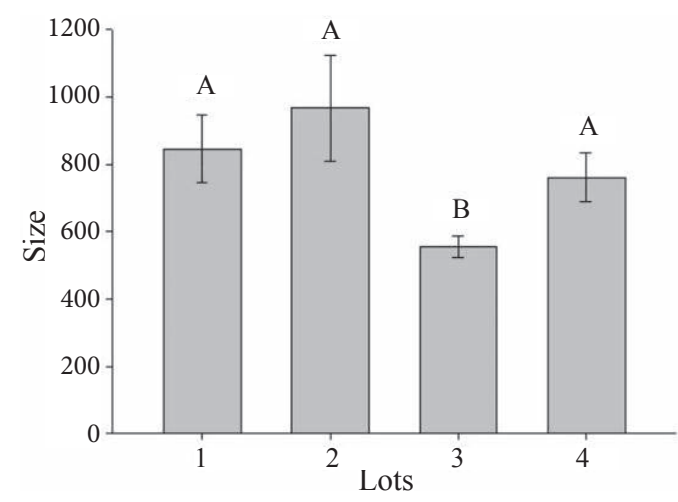

Figure 8. Quantification of the alcohol dehydrogenase enzyme activity in lots of sunflower seeds with different levels of vigor by software GelAnalyzer. Means followed by the same letter were grouped together by the Scott-Knott test $(\mathrm{p}<0.05)$. Vertical bars indicate the standard deviation of the means.

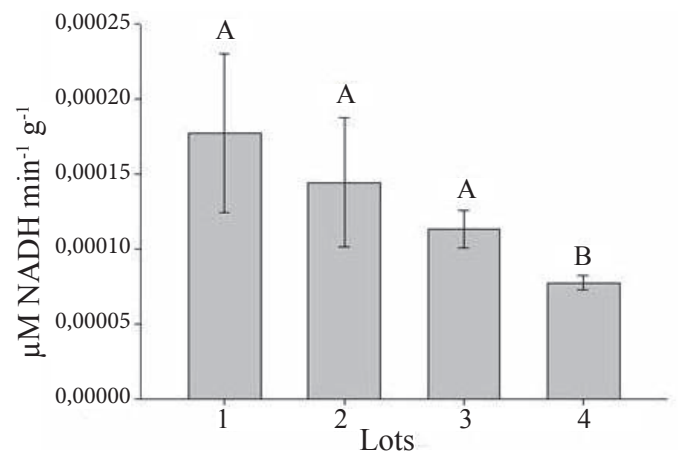

Figure 9. Quantification of the alcohol dehydrogenase enzyme activity, in lots of sunflower seeds with different levels of vigor by spectrophotometry.

Means followed by the same letter were grouped together by the Scott-Knott test $(\mathrm{p}<0.05)$. Vertical bars indicate the standard deviation of the means. 
The differences between the techniques using visual analysis and software GelAnalyzer compared to the spectrophotometric technique can be explained by the difference between the detection bases of enzymes used by the methods. While the visual analysis and software GelAnalyzer select the isoforms according to the image (presence, size and intensity of bands), the quantization process by spectrophotometry estimates the enzyme activity occurred in the predetermined time interval, depending on the reaction components in which it operates.

\section{Conclusions}

There were differences among the results obtained by different methods of analysis of the enzymes.

The results were consistent among test methods of analysis and correlated with physiological results when the catalase enzyme was evaluated.

For isoenzymatic analysis of superoxide dismutase and alcohol dehydrogenase there was a difference among the results of the methodologies, and because of these the relationship with the seeds physiological quality.

\section{References}

ABREU, L.A.S.; VEIGA, A.D.; VON PINHO, E.V.R.; MONTEIRO, F.F.; ROSA, S.D.V.F. Comportamento de sementes de cafeeiro quanto à tolerância à dessecação e ao armazenamento. Journal of Seed Science, v.36, n.4, p.399-406, 2014. http://www.scielo.br/scielo.php?pid=S2317$15372014000400003 \&$ script $=$ sci_abstract\&tlng=pt

ALFENAS, A. C. Eletroforese e marcadores bioquímicos em plantas e microrganismos. Viçosa, MG: UFV, 2006. 627 p.

ATAIIDE, G.M.; FLORES, A.V.; LIMA e BORGES, E.E. Alterações fisiológicas e bioquímicas em sementes de Pterogyne nitens Tull. durante o envelhecimento artificial. Pesquisa Agropecuária Tropical, v. 42, n. 1, p. 71-76, 2012. http:// www.scielo.br/scielo.php?pid=S1983-40632012000100010\&script=sci_arttext

BALIZA, D.P.; CAIXETA, F.; VON PINHO, E.V.R.; CUNHA, R.L.; MARTINS, D.C.; ROSA, S.D.V.F. Physiological quality of coffee seeds produced under different levels of solar radiation and maturation stages. Revista Brasileira de Sementes, v. 34, n. 3, p. 416-423, 2012. http://www.scielo. br/scielo.php?script=sci arttext\&pid=S0101-31222012000300008\&lng=en $\&$ nrm $=$ iso\&tlng $=$ en

BERJAK, P. Unifying perspectives of some mechanisms basic to desiccation tolerance across life forms. Seed Science Research, v.16, p.1-15, 2006. http://journals.cambridge.org/action/ displayAbstract fromPage $=$ online \&aid $=705716 \&$ fileId $=$ S0960258506000018

BRASIL. Ministério da Agricultura, Pecuária e Abastecimento. Regras para análise de sementes. Ministério da Agricultura, Pecuária e Abastecimento. Secretaria de Defesa Agropecuária. Brasília: MAPA/ACS, 2009. 395p. http:// www.agricultura.gov.br/arq editor/file/2946 regras analise sementes.pdf
BRAY, E.A.; BAILEY-SERRES, J.; WERETILNYK, E. Responses to abiotic stresses. In: BUCHANAN, B.B.; GRUISSEM, W.; JONES, R.L. (Ed.) Biochemistry and molecular biology of plants. Rockville: American Society of Plant Physiologists, 2000. p. 1158-1203.

BRAZ, M.R.S.; BARROS, C.S.; CASTRO, F.P.; ROSSETTOLL, C.A.V. Testes de envelhecimento acelerado e deterioração controlada na avaliação do vigor de aquênios de girassol. Revista Ciência Rural, v.38, n.7, p.18571863, 2008. http://www.scielo.br/scielo.php?script=sci_arttext\&pid=S0103$84782008000700009 \& \operatorname{lng}=$ en

BRAZ, M.R.S.; ROSSETTO, C.A.V. Correlação entre testes para avaliação da qualidade de sementes de girassol e emergência das plântulas em campo. Revista Ciência Rural, v.39, n.7, p.2004-2009, 2009. http://www.scielo.br/ scielo.php?pid=S0103-84782009000700008\&script=sci arttext

CARVALHO,E.R.;MAVAIEIE,D.P.R.;OLIVEIRA,J.A.;CARVALHO,M.V.; VIEIRA, A.R. Alterações isoenzimáticas em sementes de cultivares de soja em diferentes condições de armazenamento. Pesquisa Agropecuária Brasileira, v.49, n.12, p.967-976, 2014. http://www.scielo.br/scielo.php?script=sei abstract\&pid=S0100204X201400001200967\&lng=en\&nrm=iso\&tlng=en

COSTA, C.J.;VILLELA, F.A.; BERTONCELLO, M.R.;TILLMANN, M.A.A.; MENEZES, N.L. Expressão de isoenzimas após a pré-hidratação de sementes de ervilha. Revista Brasileira de Sementes, v.30, n.3, p.130-138, 2008. http://www. scielo.br/scielo.php?script=sci_arttext\&pid=S0101-31222008000300017

FERREIRA, D.F. Sisvar: a computer statistical analysis system. Ciência e Agrotecnologia, v.35, n. 6, p. 1039-1042, 2011. http://www.scielo.br/scielo. php?pid=S1413-70542011000600001\&script=sci arttext

GIANNOPOLITIS, C.N.; RIES, S.K. Superoxide dismutases: I. Occurrence in higher plants. Plant Physiology, v.59, n.2, p.309-314, 1977. http://www. plantphysiol.org/content/59/2/309.long

HAVIR, E.A.; MCHALE, N.A. Biochemical and developmental characterization of multiple forms of catalase in tobacco leaves. Plant Physiology, v.84, n.2, p.450-455, 1987. http://www.plantphysiol.org/content/84/2/450.long

LAZAR, I.; LAZAR, I. Gel Analyzer 2010: Freeware 1D gel electrophoresis image analysis software. 2010. http://www.gelanalyzer.com/

MAEDA, J.A.; RAZERA, L.F.; UNGARO, M.R.G. Sementes de girassol: observações preliminares sobre o teste de envelhecimento rápido. Bragantia, v.44, n.1, p.417-420, 1985. http://www.scielo.br/scielo.php?script=sci arttext\&pid=S0006-87051985000100037

MAGUIRE, J.D. Speed of germination aid in selection aid evaluation for seedling emergence and vigor. Crop Science, v.2, n.2, p. 176-177, 1962.

MARCOS-FILHO, J. Teste de envelhecimento acelerado. In KRZYZANOWSKI, F.C.; VIEIRA, R.D.; FRANÇA-NETO, J.B. (Eds.) Vigor de sementes: conceitos e testes. Londrina: ABRATES, 2005. p.1-24.

NAKADA, P.G.; OLIVEIRA, J.A.; MELO, L.C.; GOMES, L.A.A.; VON PINHO, E.V.R. Desempenho fisiológico e bioquímico de sementes de pepino nos diferentes estádios de maturação. Revista Brasileira de Sementes, v.33, n.1, p.113-122, 2011. http://www.scielo.br/pdf/rbs/v33n1/13.pdf

ROSA, S.D.V.F.; VON PINHO, E.V.R.; VIEIRA, E.S.N.; VEIGA, R.D.; VEIGA, A.D. Enzimas removedoras de radicais livres e proteínas lea associadas à tolerância de sementes de milho à alta temperatura de secagem. Revista Brasileira de Sementes, v.27, n.2, p.91-101, 2005. http://www.scielo. $\mathrm{br} / \mathrm{pdf} / \mathrm{rbs} / \mathrm{v} 27 \mathrm{n} 2 / \mathrm{a} 14 \mathrm{v} 27 \mathrm{n} 2 . \mathrm{pdf}$ 
SANTOS, C.M.R.; MENEZES, N.L.; VILLELA, F.A. Alterações fisiológicas e bioquímicas em sementes de feijão envelhecidas artificialmente. Revista Brasileira de Sementes, v.26, n.1, p.110-119, 2004. http://www.scielo.br/ scielo.php?script $=$ sci arttext\&pid $=$ S0101-31222004000100017

SANTOS, C.M.R.; MENEZES, N.L.; VILLELA, F.A. Modificações fisiológicas e bioquímicas em sementes de feijão no armazenamento. Revista Brasileira de Sementes, v.27, n.1, p.104-114, 2005. http://www.scielo.br/ scielo.php?pid=s0101-31222005000100013\&script=sci_arttext
YAMANOSHITA, T.; MASUMORI, M.; YAGI, H.; KOJIMA, K. Effects of flooding on downstream processes of glycolysis and fermentation in roots of Melaleuca cajuputi seedlings. Journal of Forest Research, v.10, n.3, p.199204, 2005. http://ink.springer.com/article/10.1007\%2Fs10310-004-0140-9

ZHANG, M.; MAEDA, Y.; FURIHATA, Y.; NAKAMAR, Y.; ESASHI, Y. A mechanism of seed deterioration in relation to the volatile compounds evolved by dry seeds themselves. Seed Science Research, v.4, p.49-56, 1994. http://journals.cambridge.org/action/displayAbstract?fromPage=online\&aid=1287676\&fileId=S0960258500001999 